\title{
Meta-Analysis on the Effect of the Quality of Health Services with the Level of Patient Satisfaction
}

\section{Siti Mar'atul Munawaroh'), Happy Nurhayati'), Andang Sudarmono3), Ervia Fahma Dhony4), Nindita Arum Veibiani4), Hesthi Krisnawatis), Wita Hana Puspita6), Dian Handayani4), Bani Dianika4), Kristuti Catur Sumarah7)}

${ }^{1)}$ Department of Public Health, Ahmad Dahlan University, Yogyakarta

${ }^{2}$ School of Health Science Aisyiyah, Klaten, Central Java

3) Regional General Hospital of Surakarta, Central Java

4)Faculty Medical Sciences, Muhammadiyah University, Surakarta, Central Java

${ }^{5)}$ Griya Husada Health Clinic, Karanganyar, Central Java

6)Faculty of Physiotherapy, EsaUnggul University, Jakarta

${ }^{7) M o j o g e d a n g}$ II Health Center, Karanganyar, Central Java

\section{ABSTRACT}

Background: patient-oriented health services are the primary strategy for health service organizations. A good service is determined by the fact that the services provided can meet the patient's needs. Patient satisfaction is an integral part of the quality assurance of health service. This study aims to analyze the quality of tangible health services with patient satisfaction in receiving health services.

Subjects and Method: Meta-analysis was performed by searching journals from direct databases such as Google Scholar, Science Direct, and PubMed using the keywords service quality, patient satisfaction, and heat service. The inclusion criteria in this study were full text from 2010-2021, with a cross-sectional study. The data analysis was carried out by RevMan 5.3 .

Cite this as:

Munawaroh SM, Nurhayati H, Sudarmono A, Dhony EF, Veibiani NA, Krisnawati H, Puspita WH, Handayani D, Dianika B, Sumarah KC (2021). Meta-Analysis on the Effect of the Quality of Health Services on the Level of Patient Satisfaction. J Health Policy Manage. 06(02): 107-115. https://doi.org/10.26911/thejhpm.2021.06.02.03.

Journal of Health Policy and Management is licensed under Creative Commons.

Attribution-NonCommercial-ShareAlike 4.0 International License.

\section{BACKGROUND}

The rapid economic growth and the challenges of the trade era have resulted in tighter competition in the business world, as well as businesses in health services, which are required to meet customer needs and desires that are not only limited to services (Tjiptono et al., 2012). Quality health
Results: Nine articles have been analyzed, showing that the quality of service had direct evidence of an effect on patient satisfaction in accessing health services $(\mathrm{aOR}=4.17 ; 95 \% \mathrm{CI}=$ 1.78 to 9.78 ; $\mathrm{p}<0.001$ ).

Conclusion: The quality of direct evidence (tangible) affects patient satisfaction in accessing health services.

Keywords: tangible, service, patient satisfaction.

\section{Correspondence:}

Siti Mar'atul Munawaroh. Ahmad Dahlan University. Jl. Prof. Dr. Soepomo, Janturan, Umbulharjo, Yogyakarta. Email: sitimaratulo8@gmail.com. Mobile +6282133295468 . services that are customer-oriented or patient-oriented are the primary strategy for health care organizations to remain during increasingly global solid competition. Improving the quality of physical facilities, available personnel, medicines, and medical devices, including human resources and professionalism, is 
necessary so that quality health services and equitable distribution of health services can be enjoyed by all people (Safrudin et al., 2012).

Service is all the efforts made by employees to fulfill the desires of their customers with services to be provided. A service is said to be suitable by the patient, determined by whether the service provided can meet the patient's needs, by using the patient's perception of the service received. Patient satisfaction is an integral part of the quality assurance of health service. Customer satisfaction is the primary indicator of the standard of a health facility. Good service quality will lead to the satisfaction of customers or service users (patients) (Hastuti et al., 2017).

This study analyzes the quality of physical evidence health services oriented to facilities and infrastructure, available personnel, drugs, and medical devices, including human resources, with patient satisfaction in receiving health services.

\section{SUBJECTS AND METHOD}

\section{Study Design}

It was a meta-analysis which is carried out by following the PRISMA Flow diagram. Search for articles was carried out on the internet using accredited journals such as Google Scholar, Science Direct, and PubMed. Article searches were conducted using the keywords "quality service" OR "patient satisfaction" AND "health service."

\section{Inclusion criteria}

Criteria, The inclusion criteria for articles reviewed are full paper articles with a crosssectional research method. Selected articles were those that presented the final results of the adjusted odds ratio (aOR), reports that performed multivariable data analysis. These articles discussed dimensions of direct evidence quality and patient satisfaction with health care.

\section{Exclusion criteria}

Criteria, The exclusion criteria for articles included case-control, cohort, and survey studies, reports published before 2011, articles featuring bivariate analysis. Reporting of final results displayed only OR, percent, and mean difference.

\section{Operational Definition of Variables}

Article search was carried out by considering the eligibility criteria, which were determined using the PICO model. The population of this study is patients who use health services with quality-oriented interventions with tangible dimensions, comparison of health services using quality dimensions other than tangible, and the result is patient received in the tangible dimension of quality.

\section{Quality of Health Services (Tangible)}

The ability was to provide the best service for customers and is a tangible thing. It means that the quality can be seen and felt directly by customers.

\section{Patient Satisfaction Level Patient}

Satisfaction is an evaluative, affective or emotional response related to the quality of services provided by health service providers and patient expectations for health services.

\section{Research Instruments}

The stages of this study follow the PRISMA Flow diagram and the assessment of the quality of research articles using the Critical Appraisal Skills Program (CASP) for CrossSectional.

\section{Data Analysis The data}

The analysis process in this study was carried out using the RevMan 5.3 application to determine the magnitude of influence and heterogeneity between the dimensions of direct evidence quality and patient satisfaction. The results of data 
Munawaroh et al./ The Effect of the Quality of Health Services with the Level of Patient Satisfaction

processing are presented in the form of a forest plot and a funnel plot.

\section{RESULTS}

The search process for articles is carried out by searching through the database according to the PRISMA Flow diagram and can be seen in Figure 1. Based on the assess- ment of the quality of the research using the critical appraisal checklist for crosssectional, the majority of respondents, nine articles included in the quantitative metaanalysis synthesis, meet the requirements in assessing the quality of the study. The following is a table of the results of the learning quality assessment.

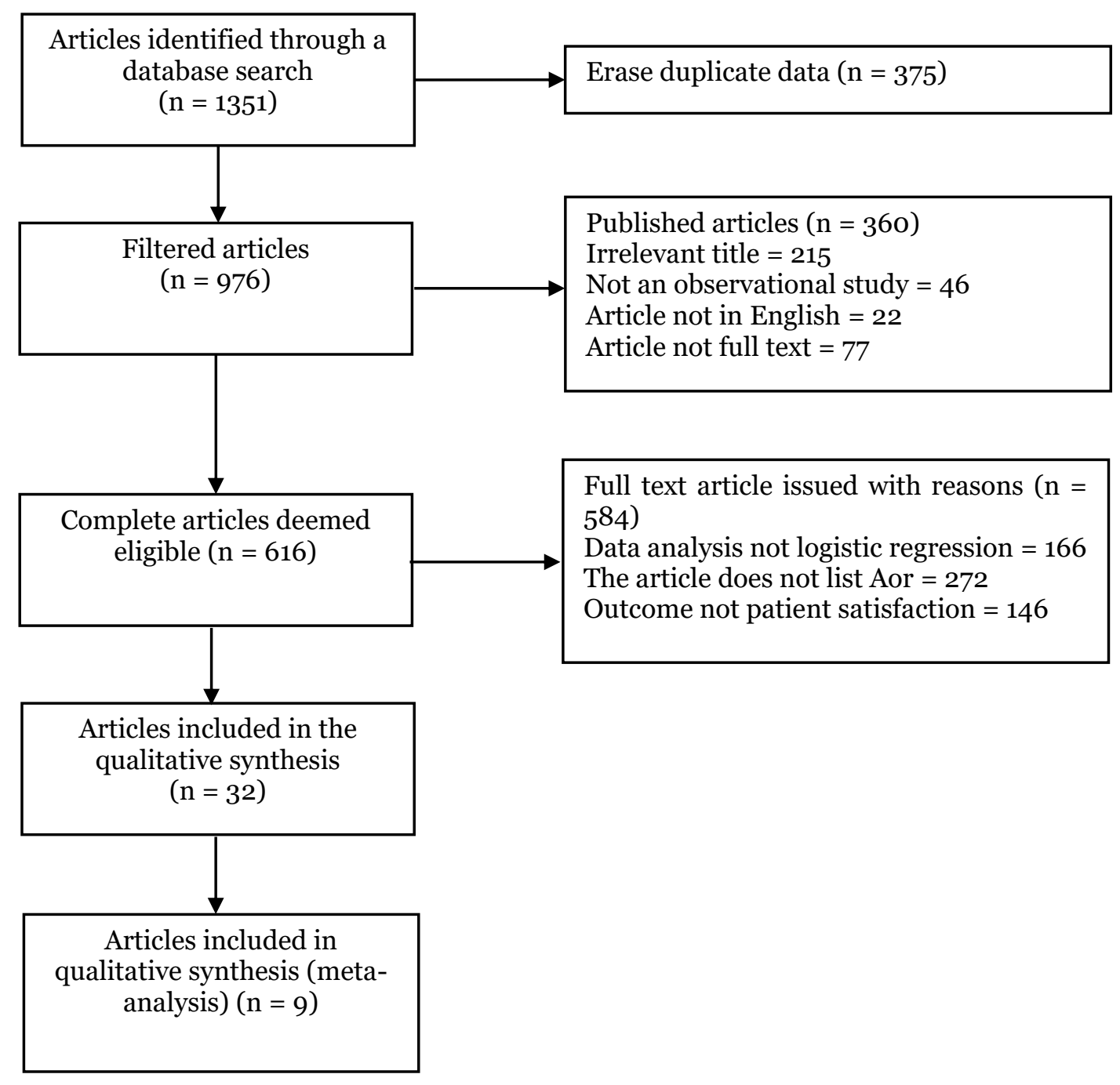

Figure 1. PRISMA Flow Diagram 
Table 1. The main description of the study on the relationship between the quality of health services physical dimensions (tangible) with patient satisfaction

\begin{tabular}{|c|c|c|c|c|c|c|}
\hline $\begin{array}{l}\text { Author, } \\
\text { Year }\end{array}$ & Title & Location & $\begin{array}{c}\text { Study } \\
\text { Design }\end{array}$ & $\begin{array}{c}\text { Sample } \\
\text { Size }\end{array}$ & $\begin{array}{c}\text { Intervention (I) And } \\
\text { Comparator (C) } \\
\end{array}$ & Outcome \\
\hline $\begin{array}{l}\text { Triana, } \\
2014\end{array}$ & $\begin{array}{l}\text { Dimensions of service quality } \\
\text { midwifery on patient satis- } \\
\text { faction program Jampersal }\end{array}$ & $\begin{array}{l}\text { Rokan Hulu } \\
\text { hospital }\end{array}$ & $\begin{array}{l}\text { Cross- } \\
\text { sectional }\end{array}$ & 92 & $\begin{array}{l}\text { I: dimensions of health service } \\
\text { quality (tangible) } \\
\text { C: not applying the dimensions } \\
\text { of health service }\end{array}$ & $\begin{array}{l}\text { quality dimensions of } \\
\text { quality (tangible) related } \\
\text { to patient satisfaction. }\end{array}$ \\
\hline $\begin{array}{l}\text { Mumu, } \\
2015\end{array}$ & $\begin{array}{l}\text { Analysis of Factors Related to } \\
\text { Patient Satisfaction in Internal } \\
\text { Medicine Polyclinic Prof. Dr. } \\
\text { RD Kandou Manado }\end{array}$ & $\begin{array}{l}\text { Prof. Dr. RD } \\
\text { Kandou } \\
\text { Manado }\end{array}$ & $\begin{array}{l}\text { Cross- } \\
\text { sectional }\end{array}$ & 96 & $\begin{array}{l}\text { I: dimensions of health service } \\
\text { quality (tangible) } \\
\text { C: not applying the dimensions } \\
\text { of health service quality }\end{array}$ & $\begin{array}{l}\text { dimensions of quality } \\
\text { (tangible) related to } \\
\text { patient satisfaction }\end{array}$ \\
\hline $\begin{array}{l}\text { Tokalese, } \\
2015\end{array}$ & $\begin{array}{l}\text { Analysis of Patient } \\
\text { Satisfaction on Perceptions of } \\
\text { Quality of Midwifery Services } \\
\text { in Inpatient Services at Prof. . } \\
\text { Dr. RD Kandou Manado }\end{array}$ & $\begin{array}{l}\text { Prof. Dr. RD } \\
\text { Kandou } \\
\text { Manado }\end{array}$ & $\begin{array}{l}\text { Cross- } \\
\text { sectional }\end{array}$ & 86 & $\begin{array}{l}\text { I: dimensions of health service } \\
\text { quality (tangible) } \\
\text { C: not applying the dimensions } \\
\text { of health service }\end{array}$ & $\begin{array}{l}\text { quality dimensions of } \\
\text { quality (tangible) related } \\
\text { to patient satisfaction. }\end{array}$ \\
\hline $\begin{array}{l}\text { Setia, } \\
2016\end{array}$ & $\begin{array}{l}\text { The Influence of Service } \\
\text { Quality on Perceptions of } \\
\text { Patient Satisfaction in the } \\
\text { Laboratory of Community } \\
\text { Health Center in Banjarbaru } \\
\text { City, 2016, }\end{array}$ & $\begin{array}{l}\text { Laboratory of } \\
\text { Community } \\
\text { Health Center } \\
\text { of Banjarbaru } \\
\text { City, }\end{array}$ & $\begin{array}{l}\text { Cross- } \\
\text { sectional }\end{array}$ & 152 & $\begin{array}{l}\text { I: dimensions of health service } \\
\text { quality (tangible) } \\
\text { C: not applying the dimensions } \\
\text { of health service }\end{array}$ & $\begin{array}{l}\text { quality the quality } \\
\text { dimension (tangible) is } \\
\text { related to satisfaction } \\
\text { patient }\end{array}$ \\
\hline $\begin{array}{l}\text { Hastuti, } \\
2017\end{array}$ & $\begin{array}{l}\text { Relationship of Service } \\
\text { Quality with Patient } \\
\text { Satisfaction of BPJS } \\
\text { Participants in Yogyakarta } \\
\text { Regional General Hospital } \\
\text { Yogyakarta Regional General }\end{array}$ & Hospital & $\begin{array}{l}\text { Cross- } \\
\text { sectional }\end{array}$ & 213 & $\begin{array}{l}\text { I: dimensions of health service } \\
\text { quality (tangible) } \\
\text { C: not applying the dimensions } \\
\text { of health service }\end{array}$ & $\begin{array}{l}\text { quality dimensions of } \\
\text { quality (tangible) related } \\
\text { to patient satisfaction }\end{array}$ \\
\hline $\begin{array}{l}\text { Nurlita, } \\
2017\end{array}$ & $\begin{array}{l}\text { Relationship of health service } \\
\text { quality with patient } \\
\text { satisfaction levels of BPJS } \\
\text { participants at Caringin health }\end{array}$ & $\begin{array}{l}\text { Caringin } \\
\text { community } \\
\text { health service }\end{array}$ & $\begin{array}{l}\text { Cross- } \\
\text { sectional }\end{array}$ & 123 & $\begin{array}{l}\text { I: dimensions of the quality of } \\
\text { health services (tangible) } \\
\text { d: not applying the dimensions } \\
\text { of health care }\end{array}$ & $\begin{array}{l}\text { quality dimensions of } \\
\text { quality (tangible) related } \\
\text { to patient satisfaction. }\end{array}$ \\
\hline
\end{tabular}


center March-May 2017

\begin{tabular}{|c|c|c|c|c|c|c|}
\hline $\begin{array}{l}\text { Purwanin } \\
\text { grum } \\
2018\end{array}$ & $\begin{array}{l}\text { Analysis of service quality } \\
\text { against patient satisfaction at } \\
\text { Pertamina Bintang Amin } \\
\text { Hospital Bandar Lampung in } \\
2018\end{array}$ & $\begin{array}{l}\text { Pertamina } \\
\text { Bintang Amin } \\
\text { Hospital } \\
\text { Bandar } \\
\text { Lampung }\end{array}$ & $\begin{array}{l}\text { Cross- } \\
\text { sectional }\end{array}$ & 120 & $\begin{array}{l}\text { I: Dimensions of health services } \\
\text { (tangible) } \\
\text { C: not applying the dimensions } \\
\text { of health service }\end{array}$ & $\begin{array}{l}\text { quality dimensions of } \\
\text { quality (tangible) related } \\
\text { to patient satisfaction. }\end{array}$ \\
\hline $\begin{array}{l}\text { Harun, } \\
2019\end{array}$ & $\begin{array}{l}\text { Analysis of factors affecting } \\
\text { health service quality on } \\
\text { patient satisfaction at } \\
\text { inpatient Pasaman health } \\
\text { center Regency } 2019\end{array}$ & $\begin{array}{l}\text { The inpatient } \\
\text { health center, } \\
\text { Pasaman } \\
\text { District }\end{array}$ & $\begin{array}{l}\text { Cross- } \\
\text { sectional }\end{array}$ & 195 & $\begin{array}{l}\text { I: dimensions of health service } \\
\text { quality (tangible) } \\
\text { C: not applying the dimensions } \\
\text { of health service }\end{array}$ & $\begin{array}{l}\text { quality dimensions of } \\
\text { quality (tangible) related } \\
\text { to patient satisfaction. }\end{array}$ \\
\hline $\begin{array}{l}\text { Hidayatul } \\
\text { lah, } 2020\end{array}$ & $\begin{array}{l}\text { The influence of service } \\
\text { quality dimensions on patient } \\
\text { satisfaction about pharma- } \\
\text { ceutical services at Narmada } \\
\text { health center West Lombok }\end{array}$ & $\begin{array}{l}\text { Community } \\
\text { health center }\end{array}$ & $\begin{array}{l}\text { Cross- } \\
\text { sectional }\end{array}$ & 99 & $\begin{array}{l}\text { I: dimensions of health service } \\
\text { quality (tangible) } \\
\text { C: not applying quality of } \\
\text { health service of dimensions } \\
\text { Quality }\end{array}$ & $\begin{array}{l}\text { dimensions (tangible) } \\
\text { relate to satisfaction } \\
\text { Patient }\end{array}$ \\
\hline
\end{tabular}


Munawaroh et al./ The Effect of the Quality of Health Services with the Level of Patient Satisfaction

\section{Forrest Plot}

The Forest Plot image shows the primary outcome interpretation of the meta-analysis process of the effect of service on patient satisfaction levels with health services. Based on the analysis results in the figure, nine articles report that service quality affects the level of patient satisfaction. Heterogeneity was high between primary studies $\left(\mathrm{I}^{2}=82 \% ; \mathrm{p}<0.001\right)$. So, a random effect model is used. In data analysis in the Forrest plot, the quality of health services increased the level of patient satisfaction by 4.17 compared to agencies that did not implement quality patient care and was statistically significant $(\mathrm{aOR}=4.17 ; 95 \% \mathrm{CI}$ $=1.78-9.78 ; \mathrm{p}<0.001)$.

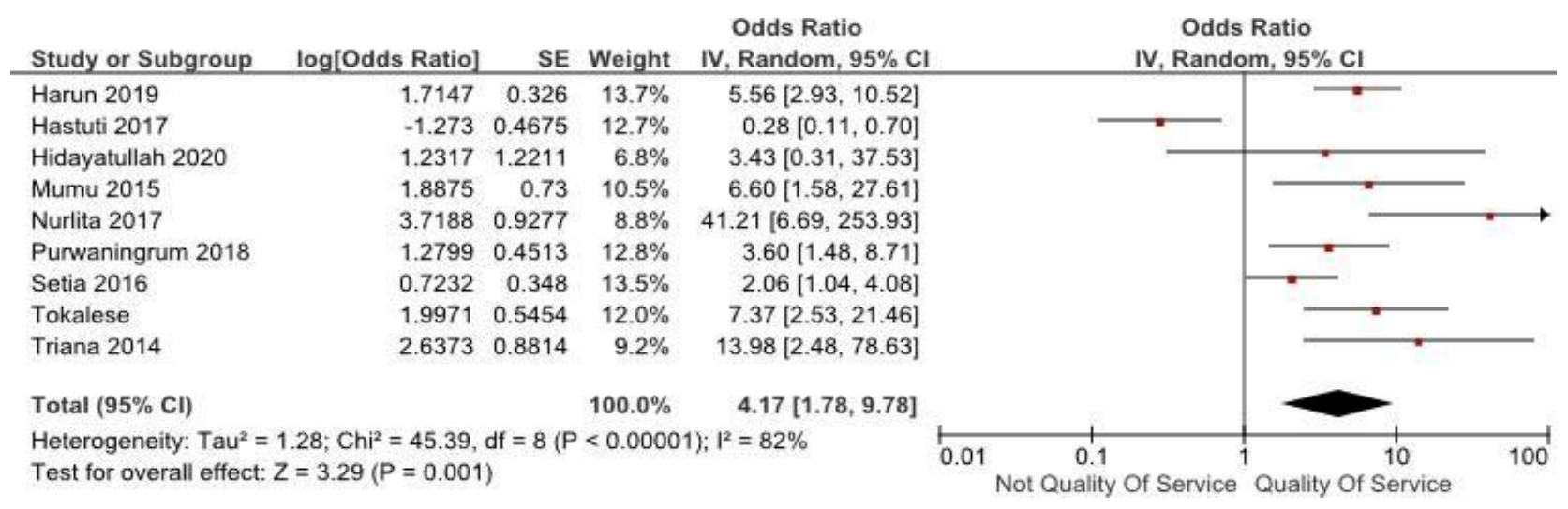

Figure 2. Forest plot

\section{Funnel Plot}

The figure below shows no publication bias where the plot distance between the right and the left looks symmetrical, and the number of requests and left plots is almost equal, that is, there are four plots on the left and five plots on the right, no plots that are on the line between right and left plot sections.

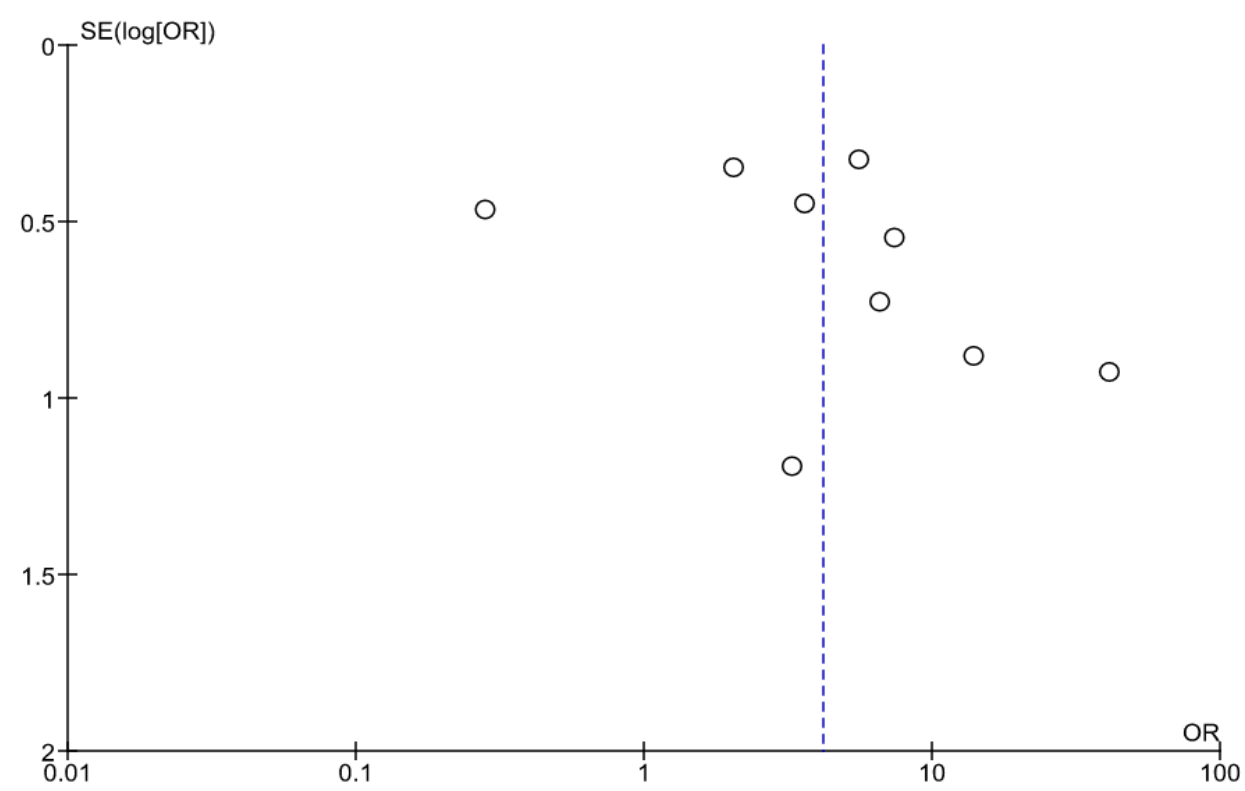

Figure 3. Funnel Plot 


\section{DISCUSSION}

This study shows that the quality of service evidence directly affects patient satisfaction in accessing health services. Similar study in Yogyakarta (Waryono et al., 2011); Sulawesi (Burhanuddin, 2016); West Lombok (Hidayatullah et al., 2020); Pekanbaru (Susmaneli et al., 2014); East Kalimantan (Hermanto et al., 2012); and Jakarta (Purnama, 2013).

Based on Ainy et al. (2012), the tangible dimension consists of three attributes with the percentage of suitability below the total mean value. First, the comfort of the waiting room; second, the comfort and tidiness of the treatment room; third, completeness, readiness, and cleanliness of the tools used. The study by Hafizurrachman (2009) states that improving the cleanliness of facilities by intensifying the efforts of cleaning service officers to work harder or intensive supervision in addition to the efforts of the to invite's the visitors to maintain the cleanliness of the hospital environment.

According to Kurniasari et al. (2006), the quality of a health service is closely related to the desire to meet the needs of health service users in the form of physical evidence so that the more perfect the fulfillment of these needs, the better the quality of service. Hizrani (2012) states that customers must be satisfied because if a customer is not satisfied with the services provided, he will look for another more enjoyable place. If the customer has fulfilled their satisfaction, the level of loyalty will be good too. It can be done by providing quality services that can meet the needs of patients. A similar study by Andriani (2009) shows that patient quality influences the level of patient satisfaction. An increase in hospital service management can realize patient satisfaction and an indicator of inpatient satisfaction at the hospital. In addition, for patients, the quality of service can be a factor in choosing a quality hospital. One way to increase patient satisfaction is with a telemedicine program (Atmojo et al., 2020). Telemedicine provides satisfaction to patients with various parameters including it can improve health care outcomes, ease of use, low cost, or cost savings, can improve communication, cut travel time to the hospital, increase access, increase self-awareness, no need to wait long to get services, reduce transportation costs, reduce the frequency of direct visits, increase independence, increase compliance and reduce readmissions (Kruse et al., 2017).

Based on the study results, it can be concluded that the quality of service is evidence directly influencing patient satisfaction in health care. The perception of direct evidence must be paid more attention to by the agency. Therefore it is necessary to make various efforts to improvement and long-term supporting factors such as improving the quality of direct evidence by educating/ training officers based on competence, improving the quality of health services both facilities and infrastructure and improving performance including attitudes and behavior of service officers.

\section{AUTHOR CONTRIBUTION}

Siti Mar'atul M, Nindita Arum V, Ervia Fahma D contributed to data processing and analysis. Happy Nurhayati, Hesti Krisnawati, Wita Hana Puspita contributed in interpreting and writing articles. Andang Sudarmono, Dian Handayani, Bani Dianika, Kristuri Catur $\mathrm{S}$ contributed in finding and sorting articles to be used in this research. 
Munawaroh et al./ The Effect of the Quality of Health Services with the Level of Patient Satisfaction

The authors state that there is no conflict of interest in this study.

\section{FUNDING AND SPONSORSHIP}

This study was not funded.

\section{ACKNOWLEDGEMENT}

We were very grateful to the database providers, namely, GoogleScholar, Research Gate, Scopus, Springer Link and Science Direct.

\section{REFERENCE}

Ainy A, Misnaniarti, Fajar NA (2012). Importance performance analysis of health social security services at the Puskesmas Swak Manajemen Pembina. Kesmas National Public Health Journal, 7 (3): 105-109. http://dx.doi.org/10.21109/kesmas.v7i3.56.

Andriani S, Sunarto (2009). The relationship between the quality of health services and the satisfaction of inpatients at the Health Service Agency of the Regional General Hospital of Magelang Regency. J Health, 2(1): 71- 79. https://doi.org/10.22219/jk.v11i2.118 94.

Atmojo JT, Sudaryanto W, Widiyanto A, Ernawati, Arradini D (2020). Telemedicine, cost-effectiveness, and patients satisfaction: A systematic review. J Health Policy Manage. 5(2): $103-107$.

https://doi.org/10.26911/thejhpm.20 20.05.02.02.

Burhanuddin N (2016). Relationship between health service quality and patients' satisfaction of RSUD Syekh Yusuf Gowa. Jurnal MKMI. 12(1).

Hafizurrachman H (2009). Kepuasan pasien dan kunjungan rumah sakit (Patient satisfaction and hospital visits). National Public Health J. 4(1):
10-17. http://dx.doi.org/10.21109/kesmas.v4i1.195.

Hastuti SKW, Mudayana AA, Nurdhilla AP, Hadiyatma D (2017). The relationship between service quality and patient satisfaction of BPJS participants at the Yogyakarta Regional General Hospital. J Public Health, 11(2): 161 168.

Hizrani M (2012). Analysis of inpatient satisfaction with service quality and its relationship with repurchase interest at X Hospital Jakarta. Journal of Indonesian Hospital Management and Administration (MARSI), 6(1).

Tjiptono F, Chandra G (2012). Service, quality satisfaction. Yogjakarta: Andi Offset.

Kruse CS, Krowski N, Rodriguez B, Tran L, Vela J, Brooks M, et al. (2017). Telehealth and patient satisfaction: A systematic review and narrative analysis. BMJ Open, 7 (8): 1-12. https://doi.org/10.1136/bmjopen-2017-016242.

Kurniasari A, Kuntjoro T (2006). Analysis of customer needs at Pijoan Baru Community Health Center Jambi Province [thesis]. Yogyakarta: Gajah Mada University Faculty of Medicine. Not published.

Purnama S (2013). Analysis of the influence of the quality of health services on the satisfaction of applicants for the licensing of traditional health services at the West Jakarta District Office of Health Services. Scientific Forum, 10 (2): $307-323$

Safrudin S, Ngisom N, Yuwono TA (2012). Hubungan mutu pelayanan kesehatan dengan kepuasan pasien rawat jalan UPT Puskesmas Gandrungmangu I Kabupaten Cilacap (Relationship quality of health services with outpatient satisfaction at Gandrungmangu I 
Munawaroh et al./ The Effect of the Quality of Health Services with the Level of Patient Satisfaction

health center in Cilacap). $\mathrm{J}$ Health Nursing. 8(2): 64-5. http://ejournal.stikesmuhgombong.ac.id/index.php/J IKK/article/view/69.

Susmaneli H, Triana A (2014). Quality dimensions of midwifery care on patient satisfaction jampersal (delivery assurance) program. National $\mathrm{J}$
Public Health. 4(1): 24-28. http://dx.doi.org/10.21109/kesmas.v8i8.414. Waryono, Purwanti NS, Palestin B (2011). The effect of community satisfaction on the utilization of health services in Yogyakarta City Health Center and Yogyakarta City Hospital in 2009. BAPPEDA Research Journal, 6(6). 